ВОЛОШЕНКО Марина - кандидат педагогічних наук, доцент, доцент кафедри психології та сочіальної роботи, Державний університет «Одеська політехніка», 1, пр. Шевченка, м. Одеса, 65044, Україна

ORCID: https://orcid.org/0000-0003-0940-3829

ResearcherID: https://publons.com/researcher/3753856/

DOI: https://doi.org/10.24919/2413-2039.13/45.2

Бібліографічний опис статті: Волошенко, М. (2021) Уявлення молоді про відповідальне батьківство. Людинознавчі студіï. Серія «Педагогіка», 13(45), 16-20, doi: https://doi.org/10.24919/24132039.13/45.2

\title{
УЯВЛЕННЯ МОЛОДІ ПРО ВІДПОВІДАЛЬНЕ БАТЬКІВСТВО
}

Анотація. Стаття присвячена основним тенденціям і трансформаціям, щуо відбуваються в інституті сім'ї на тлі змін у традиційному уявленні про шлюб. Наведено визначення поняття «батьківство» різних авторів. Воно розглядається з погляду різних наукових підходів, які розкривають складну структуру організації феномену батьківства: системного та феноменологічного. Наводиться ряд критерїв, згідно з якими можна визначити, якою мірою індивід готовий до батьківства.

Порушується проблема усвідомленого батьківства, описуються висновки щуодо результатів дослідження, присвяченого иьому питанню.

Вивченню питання сімейних цүінностей молоді, ї̈ життєвих иілей, ставлення до створення власної сім'ї та дітонародження був присвячений дослідницький проєкт, щзо включив опитування (анкетування) респондентів у віці 18-35 років. У результаті анкетування виявилося, щцо головною ичінністю молодого покоління, на думку більше половини опитаних, є емоційне, насичене життя. Крім изього, актуальними цуінностями молоді респонденти назвали матеріально забезпечене життя та розвиток, самовдосконалення.

Найменш актуальнішою иүінністю для молоді, на думку респондентів, виявилося створення власної сім' $і$, народження дітей. Можливо, це пов'язано з тим, що для представників молодшого покоління респондентів названа цінність щзе не є актуальною, оскільки вони дійсно зайняті роботою над іншими сферами життя, а для середнього покоління опитаних ияя иінність неактуальна, оскільки багато хто з них уже створив свою сім'ю та народив дітей. У ході дослідження визначено позитивні та негативні сторони батьківства очима респондентів. 3'ясовано ключові умови, необхідні респондентам для ухвалення рімення стати батьком. Наведені результати дають нам змогу підтвердити думку, що респонденти усвідомлюють труднощі, які можуть виникнути з появою дитини.

Ключові слова: батьківство, молодь, сімейні изіності.

VOLOSHENKO Maryna - PhD hab. (Education), Associate Professor, Associate Professor at the Department of Psychology and Social Work, Odesa Polytechnic National University, 1 Shevchenko Avenue, Odesa, 65044, Ukraine

ORCID: https://orcid.org/0000-0003-0940-3829

ResearcherID: https://publons.com/researcher/3753856/

DOI: https://doi.org/10.24919/2413-2039.13/45.2

To cite this article: Voloshenko, M. (2021) Uyavlennya molodi pro vidpovidalne batkivstvo. [Young people's perception of responsible fatherhood]. Human Studies. Series of Pedagogy, 13(45), 16-20, doi: https://doi.org/10.24919/2413-2039.13/45.2

\section{YOUNG PEOPLE'S PERCEPTION OF RESPONSIBLE FATHERHOOD}

Summary. The article is devoted to the main trends and transformations taking place in the institution of the family against the background of changes in the traditional notion of marriage. The definition of the concept of "fatherhood" of different authors is given. It is considered in terms of various scientific 
approaches that reveal the complex structure of the organization of the phenomenon of parenthood: systemic and phenomenological. There are a number of criteria according to which it is possible to determine the extent to which an individual is ready for parenthood.

The problem of conscious parenting is raised, the conclusions on the results of the research devoted to this question are described.

A research project involving surveys (questionnaires) of respondents aged 18-35 was devoted to the study of the family values of young people, their life goals, attitudes to starting a family and having children. As a result of the survey, it turned out that the main value of the young generation, according to more than half of respondents, is an emotional, rich life. In addition, young respondents called materially secure life and development, self-improvement, actual values.

According to the respondents, the least relevant value for young people was to start their own family and have children. Perhaps this is due to the fact that for the younger generation of respondents this value is not yet relevant, because they are really busy working on other areas of life, and for the middle generation of respondents this value is irrelevant, because many of them have created their own family. and gave birth to children. The study identified the positive and negative aspects of parenthood through the eyes of respondents. The key conditions necessary for respondents to decide to become a parent have been clarified. These results allow us to confirm the opinion that respondents are aware of the difficulties that may arise with the advent of the child.

Key words: parenthood, youth, family values.

Вступ. Розвиток сучасного суспільства спричинює зміни, що стрімко відбуваються у всіх сферах життя. Одні з найсуперечливіших тенденцій торкнулися інституту сім’ї. Згідно з А.І. Антоновим (1992), сім'я являє собою спільність людей, яка заснована на єдиній загальносімейній діяльності та пов'язана узами подружжя, батьківства та/або спорідненості, а також здійснює відтворення населення, наступність поколінь, соціалізацію дітей та підтримку існування членів сім’ї. Трансформація традиційних сімейних цінностей, гендерної рольової поведінки, поява нових форм шлюбносімейних відносин, орієнтація на малодітні та бездітні шлюби - все це та багато іншого протягом останніх десятиліть тим чи іншим чином характеризує тенденції у розвитку інституту сім’ї та шлюбу. Прагнення самореалізації (зокрема в професійній діяльності), поширення цінностей індивідуалізму, гедонізму, егоцентризму - усе це, призводить до зрушення від колективізму у бік Я.

Аналіз останніх досліджень. На тлі змін, що відбуваються, шлюб у традиційному уявленні (один на все життя), народження дітей, їхнє виховання не займають у житті молоді того місця, яке займало в житті їхніх батьків. На думку соціологів, зв'язок між трьома складовими - батьківством, подружжям та спорідненістю - втрачається. Для того, щоб народити дитину, сучасним молодим людям і дівчатам не обов'язково одружуватися і створювати сім'ю. Звідси виникає проблема ставлення молоді до батьківства загалом, до його місця у їхньому житті, до батьківства як до цінності. Розглянемо кілька визначень поняття «батьківство». Так, наприклад, М.О. Єрміхіна (2004) вважає, що батьківство - це усвідомлення духовної єдності зі шлюбним партнером щодо своїх або прийомних дітей, що $є$ інтегральною психологічною освітою особистості, яка включає сукупність ціннісних орієнтацій батька, установок і очікувань, батьківських почуттів, відносин та позицій, батьківської відповідальності та стилю виховання.

Когнітивна складова ціннісних орієнтацій подружжя, на думку автора, характеризується наявністю інформації лише на рівні переконань. Ці переконання стосуються пріоритетності цілей, типів та форм поведінки, будь-яких об'єктів у певній ієрархії. Емоційна складова реалізується безпосередньо в емоціях щодо будь-якого явища та його оцінки. 3 точки зору М.О. Єрміхіної (2004), саме емоційний аспект, що визначає переживання та почуття людини, показує значущість тієї чи іншої цінності, підштовхує до розміщення пріоритетів. Своєю чергою, поведінкова складова може бути як раціональною, так і ірраціональною, головне - спрямованість: на реалізацію ціннісної орієнтації, досягнення значущої мети, захист тієї чи іншої суб'єктивної цінності тощо. Крім цього, автор серед компонентів батьківства виділяє сімейні цінності, батьківські настанови та очікування, батьківські почуття, позиції, батьківську відповідальність, а також стиль сімейного виховання.

Розглянемо позицію А.Г. Радостєвої (2013), $з$ точки зору якої батьківство - 
«соціально-психологічний феномен, який має емоційно та оціночно забарвлену сукупність знань і навіть уявлень і переконань щодо себе як батька, які реалізуються у всіх проявах поведінкової складової батьківства». Обидва визначення є близькими за своєю суттю, загальним залишається й те, що в кожному 3 визначень батьківство має складну структуру. Своєю чергою Р.В. Овчарова (2012) розглядає батьківство як соціально-психологічне явище 3 погляду феноменологічного та системного підходів. Феноменологічний підхід має на увазі глибоке проникнення в суть феномена, абстрагування від стереотипів та шаблонів, неупередженість та контекстуальність. Розглядаючи батьківство, спираючись на принципи системного підходу, важливо звернути увагу на те, що в такому випадку феномен батьківства $є$ відносно самостійною системою, яка в той же час $є$ підсистемою щодо системи сім'ї.

Крім цього, 3 погляду Р.В. Овчарової (2012), багатогранність батьківства як феномена можна розглядати і як складну комплексну структуру індивіда, і як надіндивідуальне ціле. Автор виділяє низку планів, різні сторони яких розкривають складну структуру організації феномена батьківства: план індивідуально-особистісних особливостей жінки чи чоловіка, які впливають на батьківство, план, що розкриває батьківство стосовно системи товариств та інші. Вона пропонує представити чинники, що впливають на формування батьківства, на макрорівні - рівні суспільства, мезорівні - рівні батьківської сім'ї та мікрорівні - рівні власної сім'ї та рівні конкретної особистості.

Як було зазначено, батьківство є складним феноменом, формування якого відбувається протягом тривалого часу через низку етапів. Саме тому ми можемо говорити про готовність чи неготовність до батьківства. Варто позначити, що саме ми розумітимемо під терміном «готовність до батьківства»: це готовність до виховання дитини після того, як вона народиться і до того, щоб бути їй батьками протягом усього життя (Radosteva, 2013).

Вчені, які займаються питаннями сім'ї, шлюбу, батьківства, виділяють низку критеріїв, згідно з якими можна визначити, якою мірою індивід готовий до останнього. Серед цих критеріїв, по-перше, бажання мати дитину на рівні потреби в турботі, у догляді, яка буде вдоволена 3 появою дитини. Батьківство може вимагати зміни способу життя, інтересів, скорочення особистого часу, саме тому воно має зайняти у системі цінностей гідне місце. По-друге, необхідні навички турботи про дитину, які потребують попередньої підготовки. По-третє, індивід повинен бути емоційно автономним від своїх батьків, мати свої погляди і цінності. По-четверте, важливим критерієм є здатність повністю самостійно забезпечити дитину (незалежно від батьків та партнера). По-п’яте, людина, що готується стати батьком, повинна мати свій позитивний досвід любові, отриманий у своїй батьківській сім'ї (у разі його відсутності може бути потреба в усвідомленні та переробці негативного досвіду) (Radosteva, 2013).

Стаючи батьком, індивід бере на себе, насамперед, величезну відповідальність за життя, здоров'я та благополуччя іншої людини. Відповідальне батьківство найчастіше трактується як зацікавлене ставлення до дітей, що стосується різних сторін їхнього життя. Крім матеріальної забезпеченості, основу відповідального батьківства становлять такі якості, як здатність співпереживати дитині, турбота про іiі особистісне становлення, прагнення наповнити ії життя значними враженнями, що формують характер (Ісаков, 2014).

У дослідженні С.П. Акутіної (2009), присвяченому формуванню усвідомленого (відповідального) батьківства, взяло участь близько 1000 школярів. Дослідження ставлення школярів до створення майбутньої сім'ї показало, що, по-перше, формування відповідального батьківства охоплює всі сторони життя сім'ї. По-друге, сім'я та школа повинні комплексно взаємодіяти та виховувати духовно-моральні сімейні цінності старшокласників. По-третє, автори дослідження заявляють, що серед важливих факторів формування усвідомленого батьківства - впровадження у практику спеціальних навчальних програм із сім’ї, пропаганда ціннісного ставлення до сім’ї та шлюбу. По-четверте, взаємодія всіх соціально-педагогічних структур щодо формування у молоді відповідального батьківства як духовноморального імперативу на всіх рівнях позитивно вплине на проблему створення сім'ї та відповідального до неї ставлення.

Виклад основного матеріалу. Вивченню питання сімейних цінностей молоді, іiї життєвих цілей, ставлення до створення власної сім'ї та дітонародження був присвячений дослідницький проєкт, що включив опитування (анкетування) 70 респондентів у віці 18-35 років, які умовно були розділені на 
«молодших» (18-26 років) та «дорослих» (27-35 років). У ході дослідження було важливо розмежувати дві системи цінностей: ті, які респонденти обирають як значущі для себе й ті, які, на їхню думку, є найбільш актуальними для молоді загалом. Варто зазначити, що отримані дані не співпали.

У результаті анкетування виявилося, що головною цінністю молодого покоління, на думку більше половини опитаних, є емоційне, насичене життя. Крім цього, актуальними цінностями молоді респонденти назвали матеріально забезпечене життя та розвиток, самовдосконалення. Найменш актуальною цінністю для молоді, на думку респондентів, виявилося створення власної сім'ї, народження дітей. Також наприкінці списку опинилися здоров'я, впевненість у собі, суспільне визнання. Ми можемо припустити, що такі результати пов'язані зі стійким образом представника молоді, який склався у населення завдяки соціальним медіа: молоді женуться за емоціями, враженнями, грошима, хочуть розвиватися, їм зараз не до сім'ї, не до дітей, не до громадської думки.

У процесі дослідження було з'ясовано, що серед найважливіших для самих респондентів цінностей виявилися благополуччя близьких, здоров'я, впевненість у собі. Отримані дані говорять про пріоритет приватного життя: сім'ю, здоров'я, власне «Я». Варто зазначити, що на останньому місці у списку основних цінностей для самих респондентів виявилося створення своєї сім’і, народження дітей. Можливо, це пов'язано з тим, що для представників молодшого покоління респондентів ця цінність ще не $є$ актуальною, оскільки вони дійсно зайняті роботою над іншими сферами життя, а для середнього покоління опитаних ця цінність неактуальна, оскільки багато хто 3 них уже створив свою сім'ю та народив дітей.

У рамках дослідження було важливо дізнатися, які життєві цілі є головними для респондентів зараз. Трохи менше половини опитаних обрали головною метою свого життя духовний розвиток, самовдосконалення, далі йдуть здобуття освіти, а також здобуття гарної роботи, кар'єрне зростання. Народження дітей обрали за мету в житті лише 7\% респондентів. Таким чином, ми знову повертаємося до припущення про те, що для обох поколінь, що входять до нашої вибірки, зараз важливим $\epsilon$ саморозвиток у різних сферах: духовність, освіта, кар'єра, а виховання дітей натепер ще, або вже, або взагалі не сприймається як життєва ціль.

У ході дослідження було з'ясовано, що більше третини респондентів (37\%) сприймають батьківство як новий досвід, який приносить у життя людини позитивні та негативні аспекти в однаковій кількості. Інша частина респондентів (67\%) вважає, що батьківство несе багато щастя, але іноді можуть бути матеріальні, фізичні чи емоційні труднощі.

Таким чином, опитані чоловіки та жінки тверезо сприймають життєвий етап, коли в житті людини з'являється дитина. Респонденти не будують ілюзій навколо батьківства, але й не сприймають його як якусь важку ношу, яка не має жодних плюсів.

Крім цього, учасникам дослідження було поставлено питання про позитивні сторони батьківства. Для половини респондентів плюси батьківства полягають у можливості ділитися з кимось своїми знаннями, досвідом, перейти на новий життєвий етап, залишити продовження себе, роду.

Якщо говорити про негативні сторони батьківства, на думку 62\% опитаних, виховання дітей потребує багато сил, нервів. Респонденти вказують про ризик стати поганим, безвідповідальним батьком, побоюються, що не зуміють знайти контакту 3 дитиною. Ще одним мінусом батьківства для третини респондентів $\epsilon$ те, що діти потребують багато фінансових витрат. Такі результати дають нам змогу підтвердити думку, що респонденти усвідомлюють труднощі, які можуть виникнути з появою дитини.

У ході дослідження було виявлено ключові умови для ухвалення рішення стати батьком. Істотна частина опитаних (71\%) заявили, що для них насамперед важливо зустріти людину, 3 якою вони захочуть мати дітей. Не менш важливо для респондентів бути забезпеченою в матеріальному плані людиною, мати окремий житловий простір, досягти професійних результатів. Невипадково більше третини респондентів (40\%) заявили про те, що дитина може стати перешкодою для зміни місця проживання чи роботи. Батьківство обмежує свободу вибору, свободу переміщень. Індивід виявляється прив'язаним до дитини, оскільки відповідальний за неї.

Висновки. Підсумовуючи, слід зазначити, що тенденції, що відбуваються в інституті сім'ї та шлюбу, спричиняють зміну ставлення до батьківства. Проведені дослідження дають змогу зрозуміти, що для молоді батьківство-це 
справді складний соціально-психологічний феномен, на формування якого впливає ряд чинників. Готовність до батьківства відбувається протягом довгого часу, особливе значення в цьому процесі має емоційний, психічний та фізичний стан батьків.

\section{ЛІТЕРАТУРА}

1. Акутина С.П. Формирование осознанного отцовства у старшеклассников как духовно-нравственный императив. Известия высших учебных заведений. Поволжский регион. Гуманитарные науки. Педагогика. № 1(9), 2009. С. 133-142.

2. Антонов А.И. Кризис семьи и родительства. Проблемы родительства и планирования семьи. Москва, 1992. C. $11-27$.

3. Єрміхіна М.О. Формування усвідомленого батьківства на основі суб'єктивно-психологічних факторів : автореф. дис. ... канд. псих. наук. Казань, 2004. 23 с.

4. Ісаков О.В. Цінності батьківства у способі життя молоді. Педагогіка професійної освіти. Вчені записки ЗабДУ. 2014. № 5(58) С. 36-41.

5. Овчарова Р.В. Психологія батьківства. Москва: Академія, 2012. 362 с.

6. Радостєва А.Г. Батьківство як психологічне явище. Чинники, що впливають на його формування. Вісник ПДДПУ. Серія № 1. Психологічні та педагогічні науки. Теоретико-експериментальні дослідження. 2013. С. $100-108$.

\section{REFERENCES}

1. Akutina, S. (2009). Formyrovanye osoznannoho ottsovstva u starsheklassnykov kak dukhovno-nravstvennyy ymperatyv. [Formation of conscious fatherhood in high school students as a spiritual and moral imperative]. Yzvestyya vysshykh uchebnykh zavedenyy. Povolzhskyy rehyon. Humanytarnye nauky. Pedahohyka. № 1(9). P. 133-142. [in Russian].

2. Antonov, A. (1992). Kryzys sem'y y rodytel'stva. Problemy rodytel'stva y planyrovanyya sem'y. [Family and parenting crisis. Problems of parenting and family planning]. Moscow. P. 11-27. [in Russian].

3. Yermikhina, M. (2004). Formuvannya usvidomlenoho bat'kivstva na osnovi sub'yektyvno-psykholohichnykh faktoriv: avtoref. dys. ... kand.psykh. nauk. [Formation of conscious parenthood on the basis of subjectivepsychological factors] Kazan. 23 p. [in Russian].

4. Isakov, O. (2014). Tsinnosti bat'kivstva u sposobi zhyttya molodi. [Values of fatherhood in the way of life of youth]. Pedahohika profesiynoyi osvity. Vcheni zapysky ZabDU. № 5(58). P. 36-41[in Russian].

5. Ovcharova, R. (2012). Psykholohiya bat'kivstva. [Psychology of fatherhood]. Moscow. Academy. 362 p. [in Russian].

6. Radosteva, A. (2013). Bat'kivstvo yak psykholohichne yavyshche. Chynnyky, shcho vplyvayut' yoho formuvannya. [Fatherhood as a psychological phenomenon. Factors influencing its formation]. Visnyk PDDPU. Seriya № 1. Psykholohichni ta pedahohichni nauky. Teoretyko-eksperymental'ni doslidzhennya. P. 100-108 [in Russian]. 